\title{
Comparison of microbial load in immersion chilling water and poultry carcasses after 8,16 and 24 working hours
}

\author{
Comparação da carga microbiana em águas de pré-resfriamento e carcaças de frangos, \\ após jornadas de trabalho de 8, 16 e 24 horas
}

\section{Ricardo Cavani $^{*}$ Ruben Pablo Schocken-Iturrino ${ }^{\mathrm{I}}$ Teresa Cristina Fernandes Lopes Garcia ${ }^{\mathrm{II}}$ Adriana Cássia de Oliveira ${ }^{I I}$}

\begin{abstract}
Poultry processing facilities are known for using a great amount of water, which is mainly used on carcasses chilling stage. In Brazil, meat regulations state that each chiller tank must be emptied, cleaned and sanitized every 8 working hours. The aim of the current study was to assess the microbial load of chiller water used in poultry immersion chilling system after 8, 16 and 24 working hours in order to evaluate the reduction of water changes and chiller sanitization. Conventional physicochemical and microbiological assays were done in water supply samples $(n=69)$ to suppress interferences caused by freshwater addition; pre chilled $(n=345)$ post chilled carcasses $(n=345)$ and chiller water samples of the last stage $(n=69)$. The results showed no significant differences on microbial load samples between the three shifts suggesting that the proposed reduction may be secure and reduces the volume of wastewater that would impact the environment, besides improving the rational use of processing time.
\end{abstract}

Key words: poultry slaughterhouses, chiller water microbiological load, immersion chilling.

\section{RESUMO}

As atividades dos estabelecimentos de abate de frangos são conhecidas por utilizarem grandes volumes de água durante seus processos, principalmente no processo de resfriamento das carcaças de frangos. Parte desse volume utilizado se faz necessário, em cumprimento à legislação que determina que cada tanque do sistema de pré-resfriadores contínuos por imersão deve ser completamente esvaziado, limpo e desinfetado no final de cada período de trabalho (oito horas). O objetivo deste estudo foi comparar a carga microbiana das águas do sistema de resfriamento e das carcaças de frango ao final de oito, dezesseis e vinte e quatro horas de trabalho do abatedouro, para possível redução do número de vezes do completo esvaziamento dos tanques do sistema de resfriamento. Foram avaliadas, por meio de métodos convencionais microbiológicos e físico-químicos, amostras da água de abastecimento $(n=69)$, visando a evitar possível interferência nas contagens das águas do sistema de resfriamento, amostras de carcaças de frango antes $(n=345)$ e após $(n=345)$ sua passagem pelo sistema de resfriamento $e$ amostras de águas do último estágio do sistema de resfriamento de carcaças $(n=69)$. Os resultados obtidos demonstraram que não houve diferença significativa na carga microbiana das amostras entre as três jornadas de trabalho do estabelecimento, sugerindo que a redução é segura, diminuindo assim o volume de águas residuais e seu impacto no meio ambiente, bem como melhorando o uso racional do tempo de processamento.

Palavras-chave: abatedouro de frangos, carga microbiana de água de chiller, pré-resfriamento por imersão.

\section{INTRODUCTION}

Healthy chickens arrive at processing plants carrying many millions of bacteria, both internally and externally (CASON et al., 2004). Rearing period at the farm or the transport to the processing plant may allow bacteria to get firmly attached to feathers or skin. At the slaughterhouse, gastrointestinal content carrying bacteria can escape and contaminate carcasses and

IDepartamento de Microbiologia, Universidade Estadual Paulista (UNESP). Via de acesso Prof. Paulo Donato Castellane, s/n, Zona Rural, 14870-970, Jaboticabal, SP, Brasil. E-mail: ricardocavani@hotmail.com. *Autor para correspondência.

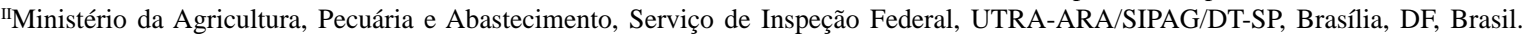


equipments, which is common in the course of processing under impaired conditions. During commercial poultry processing, eviscerated carcasses are chilled by water immersion whose reduction capacity in bacterial numbers is usually about $1 \mathrm{log}$ (BILGILI et. al, 2002). Chilling stage consists of stainless steel tanks equipped with spins to move the carcasses forward the system, through cold water, adding freshwater inflow, using continuous countercurrent system. It has been reported that such method is better for reducing bacterial numbers and incidence than parallel-flow chillers, in which clean water enters the same end of the chiller as the carcasses (KAROLYI et al., 2003; SMITH et al., 2005).

In order to manage process, food safety selfcontrol programs have been settled in Brazilian Plants (BRASIL, 2005). One of the items that have been included in these programs was zero tolerance for visible fecal contamination on carcasses entering the tanks. Thus, bacteria number during chilling stage may be impacted. Furthermore, water supply shall be maintained potable by addition of chlorine (from $0.5 \mathrm{mg}$ $\mathrm{L}^{-1}$ to $2.0 \mathrm{mg} \mathrm{L}^{-1}$ and chiller water temperature $\left(16^{\circ} \mathrm{C}\right.$ at the first stage, and $4^{\circ} \mathrm{C}$ at the last chiller), inflow of freshwater and ice per carcass ratio (minimum of $1.5 \mathrm{~L}$ carcass $^{-1}$ at the first stage and $1.0 \mathrm{~L}$ carcass $^{-1}$ at the last chiller) and chiller tanks emptiness at the end of 8 working hours are established (BRASIL, 1998; BRASIL, 2004).

The continuous use of suitable quantity of freshwater inflow, water temperature, chlorine level, carcass dwell time, and initial carcass bacterial load controls will provide improvement in the bacteriological condition of poultry (NORTHCUTT et al., 2006). Nevertheless it is possible to assure immersion chilling efficiency in controlling carcasses bacteriological load with no need of sanitizing operations in the tanks within 8 working hours, but it was suggested further studies to observe if the microflora behavior on carcasses and chiller water after that period were necessary (ISOLAN, 2007). The aim of the current study was to evaluate whether microbial load of chiller water used in poultry immersion chilling system through 8, 16 and 24 working hours suffers relevant alterations that might jeopardize bacteriological condition of the process.

\section{MATERIAL AND METHODS}

The assays were carried out in a poultry slaughterhouse located in the State of São Paulo(Brazil), slaughtering an average of 180.000 birds per day, divided in three shifts of eight working hours each. During 23 days, tap water samples ( $n=69)$, pre chilled carcasses $(n=345)$, post chilled carcasses $(n=345)$ and chiller water samples from the last chiller $(n=69)$ were collected, always at the end of the first, second and third shift, subsequently, with no sanitizing operations within those periods (eight working hours each). During the sampling procedures five pre chilled carcasses were taken. One hour and twenty two minutes ( $\pm 2 \mathrm{~min}$ ) later, the required carcasses dwell time in chilling stage, five post chilled carcasses were collected simultaneously with $500 \mathrm{~mL}$ of chiller water and $500 \mathrm{~mL}$ of tap water, from the pipe that supplied water to the chillers.

Both chiller water and tap water were evaluated by the same parameters, but chiller water samples had to be diluted: aerobic mesophilic microorganisms counts were estimated in CFU mL $\mathrm{m}^{-1}$ (colony-forming unit), plating $1 \mathrm{ml}$ of diluted chiller water $\left(10^{-2}\right)$ and $1 \mathrm{~mL}$ of tap water samples on Plate Count Agar media $\left(\right.$ Merck $^{\circledR)}$, and both of them were incubated for 48 hours at $36^{\circ} \mathrm{C}\left( \pm 1^{\circ} \mathrm{C}\right)$. To enumerate total coliforms and Escherichia coli, $100 \mathrm{ml}$ of the samples were mixed with Readycult ${ }^{\circledR}$ Coliform 100 Merck kit, but chiller water sample had to be diluted $10^{-3}$. Then, $10 \mathrm{~mL}$ from the mixtures were transferred to 10 sterile tubes which were incubated for 24 hours at $36^{\circ} \mathrm{C}\left( \pm 1^{\circ} \mathrm{C}\right)$. The results were read under ultraviolet light (365nm) and expressed in MPN mL $\mathrm{mL}^{-1}$.

Free chlorine was determined by colorimeter (Digimed $^{\circledR}$, model DM-C1), using DPD (N,N-dietil-pfenileno-diamina), reagent RBC calibrated (Brazilian Calibration Network) from 0.00 to $5.0 \mathrm{mg} \mathrm{L}^{-1} \mathrm{pH}$ was determined using a $\mathrm{pH}$-meter Micronal ${ }^{\circledR}$ calibrated with buffers. Temperature was measured using a Skewer type thermometer and the results were expressed in Celsius degrees. The freshwater volume per carcass ratio, which regulates the continuous renovation of the water volume in the chiller (capacity of $50 \mathrm{~m}^{3}$ ), was calculated by correlating the amount of consumed water registered by hygrometer to the number of broilers slaughtered within the same period. The result was expressed in liters per carcass.

The same microbiological parameters used to evaluate chiller water and tap water were applied to assess pre and post chilled carcasses, but Enterobacteriaceae and post chilled carcasses temperature were included. Pre enrichment step consisted of pooling 5 grams of each carcass, totaling $25 \mathrm{~g}( \pm 0.2 \mathrm{~g})$, which were transferred to bags containing $225 \mathrm{~mL}$ of buffered peptone water $\left(\right.$ Merck $\left.^{\circledR}\right)$. After stomached, $1 \mathrm{ml}$ of the samples was diluted $\left(10^{-4}\right.$ for pre chilled carcasses and $10^{-3}$ for post chilled carcasses) and inoculated on Petrifilm ${ }^{\mathrm{TM}}$ 3M Aerobic Count Plate. 
They were incubated for 48 hours $( \pm 3 h)$ at $35^{\circ} \mathrm{C}\left( \pm 1^{\circ} \mathrm{C}\right)$ and the results were expressed in $\mathrm{CFU} \mathrm{g}{ }^{-1}$. Also from pre enriched and stomached samples, after serial dilutions $\left(10^{-2}\right.$ pre and post chilled carcasses) aliquots of $1 \mathrm{ml}$ were spread over Petrifilm ${ }^{\mathrm{TM}} 3 \mathrm{M} \boldsymbol{E}$. coli / Coliform count plates, which were incubated for 24 hours $( \pm 2 \mathrm{~h})$ at $35^{\circ} \mathrm{C}\left( \pm 1^{\circ} \mathrm{C}\right)$ and the results were expressed in CFU $\mathrm{g}^{-1}$. To enumerate Enterobacteriaceae, after serial dilutions $\left(10^{-3}\right.$ pre chilled and $10^{-2}$ post chilled carcasses samples), $1 \mathrm{ml}$ aliquots were inoculated on Petrifilm ${ }^{\mathrm{TM}} 3 \mathrm{M}$ Enterobacteriaceae plates and incubated for 24 hours $( \pm 2 \mathrm{~h})$ at $35^{\circ} \mathrm{C}\left( \pm 1^{\circ} \mathrm{C}\right)$ and the results were expressed in CFU g ${ }^{-1}$. Post chilled carcasses temperatures were measured by inserting a skewer type thermometer into the breast and the results were expressed in Celsius degrees. Microbiological results were expressed in Log10, to statistically compare the average values using Scott-Knott Test (1974), 5\% probability.

\section{RESULTS AND DISCUSSION}

Microbiological and physicochemical analysis results of tap water supply which issued freshwater to the chiller are demonstrated on table 1. The average of aerobic mesophilic microorganisms counts ranged from $7.0 \times 10^{0} \mathrm{CFU} \mathrm{mL} \mathrm{m}^{-1}$ to $2.0 \times 10^{1} \mathrm{CFU}$ $\mathrm{mL}^{-1}$ and $1.0 \times 10^{\circ} \mathrm{CFU} \mathrm{mL} \mathrm{mL}^{-1}$ in samples taken 8,16 and 24 hours after the beginning of processing, respectively. Those results were in accordance to water standards for use in food industry recognized in Brazilian legislation which established up to 500CFU $\mathrm{mL}^{-1}$ as acceptable (BRASIL, 1997). No Escherichia coli or Coliforms colonies were recovered from the water samples, which were also in agreement to Brazilian legal requirements that regulate absence in $100 \mathrm{ml}$ as standard (BRASIL, 2004).

Free chlorine content ranged from $0.95 \mathrm{mg} \mathrm{L}^{-1}$ to $0.76 \mathrm{mg} \mathrm{L}^{-1}$ and $0.62 \mathrm{mg} \mathrm{L}^{-1}$ after 8,16 and 24 working hours, respectively, and was in accordance to legal requirements that regulates from $0.5 \mathrm{mg} \mathrm{L}^{-1}$ up to $2.0 \mathrm{mg}$ $\mathrm{L}^{-1}$ as acceptable (BRASIL, 1998). $\mathrm{pH}$ values were lower than 8.0 and met legal requirements: 7.59, 7.65 and 7.62 after 8, 16 and 24 working hours (BRASIL, 2004). Water temperature values were $2.67^{\circ} \mathrm{C}$ at the end of 8 working hours, $3.47^{\circ} \mathrm{C}$ at the end of 16 working hours and $2.44^{\circ} \mathrm{C}$ at the end of 24 working hours and were in accordance to legal requirements, lower than $4^{\circ} \mathrm{C}$. Bacteria numbers recovered from the water samples collected after 8, 16 and 24 working hours met regulatory standards and did not present significant difference between the three periods $(\mathrm{P}>0.05)$. Microbiological condition of water samples was associated to addition of chlorine and low water temperature. Water potability maintenance through the three shifts assures that water supply did not influence on microbiological results of chiller water samples.

On table 2, microbiological and physicochemical results of pre and post chilled carcasses samples, collected at the end of 8, 16 and 24 working hours are demonstrated. Aerobic mesophilic microorganisms counts recovered from pre chilled carcasses were $5.4 \times 10^{6} \mathrm{CFU} \mathrm{g}^{-1}, 3.9 \times 10^{6} \mathrm{CFU} \mathrm{g}^{-1}$ and $4.1 \times 10^{6} \mathrm{CFU} \mathrm{g}{ }^{-1}$ after 8, 16 and 24 working hours, respectively. From post chilled carcasses, average counts of Aerobic mesophilic microorganisms were $2.4 \times 10^{5} \mathrm{CFUg}^{-1}, 9.5 \times 10^{4} \mathrm{CFU} \mathrm{g}^{-1}$ and $1.4 \times 10^{5} \mathrm{CFU} \mathrm{g}^{-1}$ at the end of 8,16 and 24 working hours, respectively. Bacteriological growth on post chilled carcasses was gradually diminished through the three periods.

Coliforms recovered from pre chilled carcasses after 8 working hours were $7.8 \times 10^{5} \mathrm{CFU} \mathrm{g}^{-1}$, $1.1 \times 10^{4} \mathrm{CFU} \mathrm{g}^{-1}$ and $8.0 \times 10^{5} \mathrm{CFU} \mathrm{g}^{-1}$ at the end of 8,16 and 24 working hours, respectively. From post chilled carcasses, the average values were $1.4 \times 10^{4} \mathrm{CFU} \mathrm{g}{ }^{-1}$, $1.6 \times 10^{3} \mathrm{CFU} \mathrm{g}^{-1}$ and $3.6 \times 10^{3} \mathrm{CFU} \mathrm{g}^{-1}$ at the end of 8,16 and 24 working hours, respectively. A reduction of 1 $\log$ on bacterial average number when the results of

Table 1 - Results of microbiological and physicochemical analysis of tap water used to supply the chillers.

\begin{tabular}{|c|c|c|}
\hline Parameter & Working hours & Result \\
\hline \multirow{3}{*}{$\begin{array}{l}\text { Aerobic Mesophilic } \\
\text { microorganisms count } \\
\left(\log _{10}\right)\end{array}$} & 08 hours & $0.85 \mathrm{a} 1$ \\
\hline & 16 hours & $1.30 \mathrm{a} 1$ \\
\hline & 24 hours & $0.00 \mathrm{a} 1$ \\
\hline \multirow{3}{*}{ Coliforms $\left(\log _{10}\right)$} & 08 hours & $0.00 \mathrm{a} 1$ \\
\hline & 16 hours & $0.00 \mathrm{a} 1$ \\
\hline & 24 hours & $0.00 \mathrm{a} 1$ \\
\hline \multirow{3}{*}{$\begin{array}{l}\text { Escherichia coli } \\
\left(\log _{10}\right)\end{array}$} & 08 hours & $0.00 \mathrm{a} 1$ \\
\hline & 16 hours & $0.00 \mathrm{a} 1$ \\
\hline & 24 hours & $0.00 \mathrm{a} 1$ \\
\hline \multirow{3}{*}{ Free chlorine (mg L ${ }^{-1}$ ) } & 08 hours & $0.95 \mathrm{a} 2$ \\
\hline & 16 hours & $0.76 \mathrm{a} 1$ \\
\hline & 24 hours & $0.62 \mathrm{a} 1$ \\
\hline \multirow{3}{*}{$\mathrm{pH}$} & 08 hours & $7.59 \mathrm{a} 1$ \\
\hline & 16 hours & 7.65 a1 \\
\hline & 24 hours & $7.62 \mathrm{a} 1$ \\
\hline \multirow{3}{*}{ Temperature $\left({ }^{\circ} \mathrm{C}\right)$} & 08 hours & $2.67 \mathrm{a} 1$ \\
\hline & 16 hours & $3.47 \mathrm{a} 2$ \\
\hline & 24 hours & 2.44 a1 \\
\hline
\end{tabular}

Average values identified with the same code (a1) does not differ from them $(\mathrm{P}>0.05)$, according to Scott-Knott Test. 
Table 2 - Microbiological results and temperature of pre and post chilled broiler carcasses sampled after 8, 16 and 24 working hours.

\begin{tabular}{lccc}
\hline Parameters & Working Hours & Analysis Result Pre Chilled Carcasses & Analysis Result Post Chilled carcass. \\
\hline $\begin{array}{l}\text { Aerobic mesophilic } \\
\text { microorganisms count }\end{array}$ & 08 hours & $6.74 \mathrm{a} 1$ & $5.37 \mathrm{a} 1$ \\
$\left(\log _{10}\right)$ & 16 hours & $6.59 \mathrm{a} 1$ & $4.98 \mathrm{a} 1$ \\
& 24 hours & $6.61 \mathrm{a} 1$ & $5.14 \mathrm{a} 1$ \\
& & & $4.13 \mathrm{a} 2$ \\
Coliforms & 08 hours & $5.89 \mathrm{a} 1$ & $3.20 \mathrm{a} 1$ \\
$\left(\log _{10}\right)$ & 16 hours & $4.03 \mathrm{a} 1$ & $3.55 \mathrm{a} 1$ \\
& 24 hours & $5.90 \mathrm{a} 1$ & $3.86 \mathrm{a} 1$ \\
& & & $2.77 \mathrm{a} 1$ \\
Escherichia coli & 08 hours & $5.33 \mathrm{a} 1$ & $3.42 \mathrm{a} 1$ \\
$\left(\log _{10}\right)$ & 16 hours & $3.60 \mathrm{a} 1$ & $3.40 \mathrm{a} 1$ \\
& 24 hours & $5.34 \mathrm{a} 1$ & $3.49 \mathrm{a} 1$ \\
Enterobacteriaceae & & & $3.70 \mathrm{a} 2$ \\
$\left(\log _{10}\right)$ & 08 hours & $5.79 \mathrm{a} 1$ & $3.03 \mathrm{a} 1$ \\
& 16 hours & $5.01 \mathrm{a} 1$ & $3.16 \mathrm{a} 1$ \\
Temperature $\left({ }^{\circ} \mathrm{C}\right)$ & 24 hours & $5.93 \mathrm{a} 1$ & $3.73 \mathrm{a} 2$ \\
\hline
\end{tabular}

Average values identified with the same code (a1) does not differ from them ( $\mathrm{P}>0.05)$, according to Scott-Knott Test.

post chilled carcasses were compared through the three shifts has been noticed.

Escherichia coli counts recovered from pre chilled carcasses were $2.1 \times 10^{5} \mathrm{CFU} \mathrm{g}^{-1}, 4.0 \times 10^{4} \mathrm{CFU} \mathrm{g}^{-1}$ and $2.2 \times 10^{5} \mathrm{CFU} \mathrm{g}^{-1}$ at the end of 8,16 and 24 working hours, respectively. From post chilled carcasses, the counts were $2.3 \times 10^{3} \mathrm{CFU} \mathrm{g} \mathrm{g}^{-1}, 5.9 \times 10^{2} \mathrm{CFU} \mathrm{g} \mathrm{g}^{-1}$ and $2.6 \times 10^{3} \mathrm{CFU} \mathrm{g}^{-1}$ at the end of the three periods. It was also observed a reduction of 1 log on bacterial number, when the microbiological results of carcasses collected at the end of the first period was compared to the second one. However from the second to the last period microbiological results were very similar. Enterobacteriaceae counts recovered from pre chilled carcasses were $6.2 \times 10^{5} \mathrm{CFU} \mathrm{g}^{-1}, 1.0 \times 10^{5} \mathrm{CFU} \mathrm{g}^{-1}$ and $8.6 \times 10^{5} \mathrm{CFU} \mathrm{g}^{-1}$ collected after 8,16 and 24 working hours, respectively. From post chilled carcasses the average numbers were $2.5 \times 10^{3} \mathrm{CFU} \mathrm{g}^{-1}, 3.1 \times 10^{3} \mathrm{CFU} \mathrm{g}^{-1}$ and $5.0 \times 10^{3} \mathrm{CFU} \mathrm{g}^{-1}$ after 8,16 and 24 working hours, respectively. Enterobacteriaceae numbers were similar, comparing post chilled carcasses results collected at the end of the three periods. Carcasses temperatures were kept in accordance to Brazilian legal requirements (BRASIL, 1998) which establish post chilled carcasses temperature must be lower than $7^{\circ} \mathrm{C}$. Average values ranged from $3.03^{\circ} \mathrm{C}, 3.16^{\circ} \mathrm{C}$ and $3.73^{\circ} \mathrm{C}$ at the end of the three shifts (8 working hours each). Low temperature was due to addition of cold freshwater and ice into the chillers and impacted overall reduction of bacterial isolates on post chilled carcasses. No significant difference $(\mathrm{P}>0.05)$ was found on microbiological results recovered from pre chilled carcasses when the three periods were compared. Such uniformity of results was explained by continuous procedures carried out during monitoring and removal of visible gastrointestinal contamination on pre chilled carcasses. That contributes to avoid cross contamination during immersion chilling and improves bacteriological condition of post chilled carcasses. Potentially, one or a few dirty carcasses could crosscontaminate many clean carcasses through close contact with carcasses or water in the chiller (SMITH et al., 2005). The Food Safety Inspection Service (FSIS) has decided that overall product safety, whether impaired from direct contamination before the chiller or from cross-contamination in the chiller, can be improved by mandating zero tolerance for visible fecal contamination of carcasses entering the chiller (ESTADOS UNIDOS, 2004)

Post chilled carcasses demonstrated no significant difference on Aerobic mesophilic counts, Escherichia coli and Enterobacteriaceae numbers $(\mathrm{P}>0.05)$, but on Coliforms numbers $(\mathrm{P}<0.05)$. Assessment of microbiological load on pre and post chilled carcasses demonstrates immersion chilling efficiency on reduction microorganisms. As explained before, zero tolerance for visible fecal contamination on carcasses entering the chiller, associated to low freshwater temperature, addition of chlorine to maintain potable status of water supply and water $\mathrm{pH}$ control 
improves bacteriological condition of post chilled carcasses.

Those findings corroborate the ones presented by BLOOD \& JARVIS (1974) whom observed during their studies carried out in chiller water samples from five poultry processing plants located in the United Kingdom, that microbiological condition of chilled poultry carcasses were influenced by the amount of water in the chiller, freshwater inflow, water volume per carcass ratio and the initial bacterial load. BILGILI et al. (2002) reported the reduction in bacterial numbers caused by chilling was usually about $1 \log$ when 1080 carcasses from seven slaughterhouses in Alabama, USA, were evaluated. Others authors have been related that poultry carcass chilling stage reduces the overall bacteria numbers: aerobic mesophilic counts LILLARD (1990), JAMES et al. (1992), BILGILI et al. (2002) and NORTHCUTT et al. (2003); Coliforms, KAROLYI et al. (2003) and CASON et al. (2004); Enterobacteriaceae, LILLARD (1990) and JAMES et al. (1992); Escherichia coli, LILLARD (1990), JAMES et al. (1992); BILGILI et al. (2002); KAROLYI et al. (2003); NORTHCUTT et al. (2003) and CASON et al. (2004).

Means for aerobic mesophilic microorganisms count, coliforms, Escherichia coli, free Chlorine and $\mathrm{pH}$ of chiller water samples collected 8,16 and 24 hours after the beginning of processing, including chiller water temperature, volume of water per carcass ratio and speed of slaughtering line were shown on table 3 . The average number of colonies of aerobic mesophilic microorganisms recovered from chiller water were $8.4 \times 10^{3} \mathrm{CFU} \mathrm{mL}{ }^{-1}$ when the samples were collected 8 hours, $7.7 \times 10^{3} \mathrm{CFU} \mathrm{mL}^{-1} 16$ hours and $5.2 \mathrm{x} 10^{3} \mathrm{CFU} \mathrm{mL}^{-1} 24$ hours after the beginning of processing, demonstrating that bacteria numbers gradually diminished through the three shifts. Coliforms counts were $1.3 \times 10^{4} \mathrm{MPN} 100 \mathrm{~mL}^{-1}$, $1.7 \times 10^{4} \mathrm{MPN} 100 \mathrm{~mL}^{-1}$ and $1.4 \times 10^{4} \mathrm{MPN} 100 \mathrm{~mL}^{-1}$ when samples were taken at the end of 8,16 and 24 working hours, respectively, demonstrating very similar and stable results, with no significant difference $(\mathrm{P}>0.05)$.

Escherichia coli isolates ranged from 1.0x10 $0^{4} \mathrm{MPN}$ $100 \mathrm{~mL}^{-1} ; 1.4 \times 10^{4} \mathrm{MPN} 100 \mathrm{~mL}^{-1}$ and $9.8 \times 10^{3} \mathrm{MPN} 100 \mathrm{~mL}^{-}$ ${ }^{1}$ at the end of the first, second and third shift, demonstrating reduction of $1 \log$ through the three periods. Actually, overall microbiological results of chiller water samples presented above did not demonstrate significant difference $(\mathrm{P}>0.05)$ among the three shifts. Once again, control points and monitoring described in the Food Safety self control programs (zero tolerance for visible fecal contamination, low water temperature, addition of freshwater, chlorination of supply water) influenced bacteriological condition. Low chlorine levels found in chiller water samples (0.03mg L $\mathrm{m}^{-1}$ at the end of 8 working hours and absence 16 and 24 hours later) are correlated to the action of chlorine oxidation over organic matter suspended in water (GALHARDO et al., 2006). pH values were 7.17; 7.24 and 7.21 at the end of the first, second and third shifts, respectively. They were considered constant, so may not be related to bacterial colonies growth (FORSYTHE, 2005). Chiller water temperature at the moment the samples were taken was $1.27^{\circ} \mathrm{C}, 1.61^{\circ} \mathrm{C}$ and $1.75^{\circ} \mathrm{C}, 8,16$ and 24 working hours later, respectively.

The average water volume per carcass ratio reached at the end of the three shifts were $1.24 \mathrm{~L}$ carcass $^{-1}, 1.15 \mathrm{~L}$ carcass $^{-1}$ and $1.54 \mathrm{~L}$ carcass $^{-1}$, respectively and were higher than the ones required

Table 3 - Results of microbiological and physicochemical analysis of chiller water after 8, 16 and 24 working hours.

\begin{tabular}{|c|c|c|}
\hline Parameter & $\begin{array}{l}\text { Working } \\
\text { hours }\end{array}$ & $\begin{array}{c}\text { Analysis } \\
\text { Result }\end{array}$ \\
\hline $\begin{array}{l}\text { Aerobic Mesophilic } \\
\text { microorganisms count } \\
\left(\log _{10}\right)\end{array}$ & $\begin{array}{l}08 \text { hours } \\
16 \text { hours } \\
24 \text { hours }\end{array}$ & $\begin{array}{l}3.92 \mathrm{a} 1 \\
3.88 \mathrm{a} 1 \\
3.72 \mathrm{a} 1\end{array}$ \\
\hline Coliforms $\left(\log _{10}\right)$ & $\begin{array}{l}08 \text { hours } \\
16 \text { hours } \\
24 \text { hours }\end{array}$ & $\begin{array}{l}4.12 \mathrm{a} 1 \\
4.22 \mathrm{a} 1 \\
4.14 \mathrm{a} 1\end{array}$ \\
\hline Escherichia coli $\left(\log _{10}\right)$ & $\begin{array}{l}08 \text { hours } \\
16 \text { hours } \\
24 \text { hours }\end{array}$ & $\begin{array}{l}4.02 \mathrm{a} 1 \\
4.15 \mathrm{a} 1 \\
3.99 \mathrm{a} 1\end{array}$ \\
\hline Free chlorine (mg L ${ }^{-1}$ ) & $\begin{array}{l}08 \text { hours } \\
16 \text { hours } \\
24 \text { hours }\end{array}$ & $\begin{array}{l}0.03 \mathrm{a} 1 \\
0.00 \mathrm{a} 1 \\
0.00 \mathrm{a} 1\end{array}$ \\
\hline $\mathrm{pH}$ & $\begin{array}{l}08 \text { hours } \\
16 \text { hours } \\
24 \text { hours }\end{array}$ & $\begin{array}{l}7.17 \mathrm{a} 1 \\
7.24 \mathrm{a} 1 \\
7.21 \mathrm{a} 1\end{array}$ \\
\hline Temperature $\left({ }^{\circ} \mathrm{C}\right)$ & $\begin{array}{l}08 \text { hours } \\
16 \text { hours } \\
24 \text { hours }\end{array}$ & $\begin{array}{l}1.27 \mathrm{a} 1 \\
1.61 \mathrm{a} 1 \\
1.75 \mathrm{a} 1\end{array}$ \\
\hline $\begin{array}{l}\text { Water volume per carcass } \\
\text { Ratio (L/carcass) }\end{array}$ & $\begin{array}{l}08 \text { hours } \\
16 \text { hours } \\
24 \text { hours }\end{array}$ & $\begin{array}{l}1,24 \text { a1 } \\
1,15 \text { a1 } \\
1,54 \text { a2 }\end{array}$ \\
\hline $\begin{array}{l}\text { Slaughtering speed } \\
\text { (carcasses/min) }\end{array}$ & $\begin{array}{l}08 \text { hours } \\
16 \text { hours } \\
24 \text { hours }\end{array}$ & $\begin{array}{l}142 \mathrm{a} 1 \\
146 \mathrm{a} 2 \\
147 \mathrm{a} 2\end{array}$ \\
\hline
\end{tabular}

Average values identified with the same code (a1) does not differ from them $(\mathrm{P}>0.05)$, according to Scott-Knott Test. 
to last chilling stage in Brazilian legislation - 1.00L carcass $^{-1}$ (BRASIL, 1998). The previous results reveal one of the most essential facts that affected chiller water microbiology: cold freshwater inflow reduced bacterial numbers. The average slaughtering speed was 142 broilers/minute when the samples were collected at the end of the first shift, 146 broilers/ minute after 16 working hours and 147 broilers/minute 24 hours after the beginning of processing, depending on the number of broilers to be slaughtered and the processing capacity.

Similar results were found by BARROS et al. (2007) while looking for coliforms, Escherichia coli, Enterococcus spp and Salmonela spp in chiller water samples collected from poultry and pigs slaughterhouses located in the State of São Paulo (Brazil). Reduction on bacteria numbers were explained by low water temperature impact. NORTHCUTT et al. (2007) reported similar results of chiller water samples analysis from three chillers at a poultry processing plant working in two shifts, in the USA. In this case, no significant difference was indicated between the two shifts, concerning Escherichia coli, coliforms, Campylobacter sp numbers and Salmonella spp incidence. The findings presented in the current study demonstrate that since the food safety self-control programs (industry maintenance and equipment, changing rooms and toilets, lighting, ventilation, water supply, waste water, pest control, cleaning and sanitation, hygiene, hygienic habits and health workers, sanitary operations procedures, control of raw materials, ingredients and packaging materials, temperature control, calibration and measurement instruments, hazards analysis and critical control points, microbiological testing, certification of products, animal welfare, control of water addition in products) are implemented and the immersion chilling system technical requirements are respected; it is possible to guarantee the chilling process efficiency in reducing microbiological load without emptying and sanitizing the tanks every 8 working hours.

\section{CONCLUSION}

Since the volume of freshwater inflow, temperature and $\mathrm{pH}$ of chiller water are controlled and associated to chlorination of potable water and control of initial microbiological load of pre chilled carcasses, extending cleaning and sanitizing frequency of chiller tanks to periods longer than 8 working hours, microbiological quality of post chilled poultry carcasses won't be impaired. Such countermeasure may contribute to coherent use of water resource and reduce the volume of waste water that would impact the environment, besides rational use of processing time.

\section{REFERENCES}

BARROS, L.S.S. et al. Potential microbiological contamination of effluents in poultry and swine abattoirs. Epidemiology and Infection, v.135, p.505-518, 2007. Available from: < http://journals.cambridge.org/action/ displayAbstract? fromPage $=$ online $\&$ aid $=939132>$. Accessed: Feb 19, 2009. doi: 10.1017/S0950268806006972.

BILGILI, S.F. et al. Visible ingesta on prechill carcasses does not affect the microbiological quality of broiler carcasses after immersion chilling. Journal Applied Poultry Research, v.11, p.233-238, 2002.

BLOOD, R.M.; JARVIS, B. Chilling of poultry: the effects of process parameters on the level of bacteria in spin-chiller waters. International Journal of Food Science and Technology, v.9, p.157-169, 1974. Available from: < http:/ /www3.interscience.wiley.com/journal/120071072/ abstract?CRETRY=1\&SRETRY $=0>$. Accessed: Jan 20, 2009. doi: 10.1111/j.1365-2621.1974.tb01759.

BRASIL. Decreto n. 2244 de 10 de Novembro de 1997. Altera dispositivos do Decreto n. 30.691, de 29 de Março de 1952, que aprovou o Regulamento da inspeção industrial e sanitária de produtos de origem animal, alterado pelos Decretos n. 1.255, de 25 de Julho de 1962, n. 1.236, de 2 de Setembro de 1994, e n. 1,812, de 8 de fevereiro de 1996. Diário Oficial \{da\} União, Ministério da Agricultura, Pecuária e Abastecimento, Secretaria de Defesa Agropecuária. Brasília DF, 04 jun. 1997.

BRASIL. Portaria n. 210 de 10 de Novembro de 1998. Regulamento técnico da inspeção tecnológica e higiênicosanitária de carne de aves. Diário Oficial da União, Ministério da Agricultura, Pecuária e Abastecimento, Secretaria de Defesa Agropecuária. Brasília DF, 26 nov. 1998.

BRASIL. Portaria n. 518 de 25 de Março de 2004. Estabelece os procedimentos e responsabilidades relativas ao controle e vigilância da qualidade de água para consumo humano. Diário Oficial \{da\} União, Ministério da Saúde. Brasília DF, 26 mar. 2004.

BRASIL. Circular n. 175 de 16 de Maio de 2005. Procedimentos de verificação dos programas de autocontrole (Versão Preliminar). Diário Oficial da União, Ministério da Agricultura, Pecuária e Abastecimento. Secretaria de Defesa Agropecuária. Departamento de Inspeção de Produtos de Origem Animal. Coordenação Geral de Programas Especiais. Brasília DF, 16 maio, 2005.

CASON, J.A. et al. Effect of prechill fecal contamination on numbers of bacteria recovered from broiler chicken carcasses before and after immersion chilling. Journal of Food Protection, v.67, p.1829-1833, 2004.

ESTADOS UNIDOS. Directive 6420.2 de 31 de Março de 2004. Verification of procedures for controlling fecal material, ingesta, and milk in slaughter operations. 
United States Department of Agriculture, Food Safety Inspection Service. Washington, DC.

FORSYTHE, S.J. Microbiologia da segurança alimentar. Porto Alegre:Artmed, 2005. 424p.

GALHARDO, J.A. et al. Eficácia dos tanques de préresfriamento na redução de contaminação bacteriana em carcaças de frango. Semina Ciências Agrárias, v.27, n.4, p.647-656, 2006.

ISOLAN, L.W. Estudo da eficiência da etapa de préresfriamento por imersão em água no controle da qualidade microbiológica das carcaças de frango. 2007. 81f. Dissertação (Mestrado em Ciências Veterinárias) Faculdade de Veterinária, Universidade Federal do Rio Grande do Sul, RS.

JAMES, W.O. et al. Effects of countercurrent scalding and postscald spray on the bacteriologic profile of raw chicken carcasses. Journal of the American Veterinary Medical Association, v.201, p.705-708, 1992.

KAROLYI, L.G. et al. Bacterial population in counter flow and parallel flow water chilling of poultry meat. European Food Research and Technology, v.217, p.412-415, 2003. Available from: < http://www.springerlink.com/content/ vexdqf4j8ecgty20/>. Accessed: Mar 20, 2009. doi: 10.1007/ s00217-003-0772-6.
LILLARD, H.S. The impact of commercial processing procedures on the bacterial contamination and crosscontamination of broiler carcasses. Journal of Food Protection, v.53, p.202-204, 1990.

NORTHCUTT, J.K. et al. Numbers of bacteria recovered from broiler carcasses and chiller water treated with hypochlorous and carbonic acids. Poultry Science, v.86, p.383-384, 2007.

NORTHCUTT, J.K. et al. Broiler carcass bacterial counts after immersion chilling using either a low or high volume of water. Poultry Science, v.85, p.1802-1806, 2006.

NORTHCUTT, J.K. et al. Effect of broiler age, feed withdrawal, and transportation on levels of coliforms, Campylobacter, Escherichia coli and Salmonella on carcasses before and after immersion chilling. Poultry Science, v.82, p.169-173, 2003.

SCOTT, A.J.; KNOTT, M.A. Cluster analysis method for grouping means in the analysis of variance. Biometrics, v.30, p.507-512, 1974.

SMITH, D.P. et al. Effect of fecal contamination and crosscontamination on numbers of coliform, Escherichia coli, Campylobacter and Salmonella on immersionchilled broiler carcasses. Journal of Food Protection, v.68, p.1340-1345, 2005. 